\section{Growing Profitable Apple Orchards in Replant Sites: An Interdisciplinary Team Approach in Washington State}

\author{
Mike Willett', T.J. Smith², \\ A.B. Peterson, ${ }^{1}, \mathrm{H}$. Hinman', \\ R.G. Stevens ${ }^{4}$, T. Ley ${ }^{4}$, \\ P. Tvergyak ${ }^{2}$, K.M. Williams ${ }^{5}$, \\ K.M. Maib ${ }^{6}$, and J.W. Watson
}

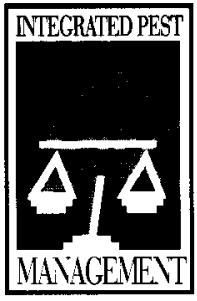

Additional index words. specific apple replant disease, technology transfer, evaluation, needs assessment

Summary. In the mid-1980s, a statewide educational program was initiated to help improve productivity in replanted apple orchards. This effort began with a study of the background of the problem in Washington and an assessment of the problems growers faced when replanting orchards. An array of potential limiting factors were identified-most important, specific apple replant disease (SARD)-but also low soil $\mathrm{pH}$, poor irrigation practices, arsenic (As) spray residues in the soil, soil compaction, nematodes, nutrient deficiencies, and selection of the appropriate orchard system. The educational program was delivered using a variety of methods to reach audience members with different learning styles and to provide various levels of technical information, focusing on ways to correct all limiting factors in replant situations. Results have been: Acceptance of soil fumigation as a management tool: increased recognition of soil physical, chemical, and moisture problems; reduced reliance on seedling rootstock, and an increase in the use of dwarfing, precocious understocks; and better apple tree growth and production in old apple orchard soils.

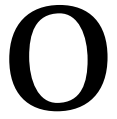
vercoming poor growth in orchards where a "second planting of a fruit crop species follow(s) the same or a closely related species on a given site...has

Cooperative Extension, Washington State University, Pullman, WA 99164-6414. The cost of publishing this paper was defrayed in part by the payment of page charges. Under postal relations, this paper therefore mutt be hereby marked advertisement solely to indicate this fact.

${ }^{1}$ Area Tree Fruit Agent, Yakima County Cooperative Extension, 128 N. 2nd St., Yakima, WA 98901-2631.

${ }^{2}$ Area Tree Fruit Agent, Chelan County Cooperative Extension, 400 Washington St., Wenatchee, WA 98801-2855.

${ }^{3}$ Extension Agricultural Economist, Department of Agricultural Economics, Washington State University, Pullman, WA 99164-6210.

${ }^{4}$ Extension Soil Scientist and Extension Irrigation Engineer, respectively, Irrigated Agriculture Research and Extension Center, Rt. 2, Box 2953-A, Prosser, WA 99350-9687.

${ }^{5}$ Extension Hortculturist, Tree Fruit Research and Extension Center, 1100 N. Western Avenue, Wenatchee, WA 98801.

${ }^{6}$ Area Tree Fruit Agent, Grant County Cooperative Extension, Courthouse, P.O. Box 37, Ephrata, WA 98823

'Area Tree Fruit Agent, Beaten County Cooperative Extension, 1121 Dudley Avenue, Prosser, WA 99350. been a recognized problem for over 200 years" (Savory, 1966). When these plantings are apples, the problem is referred to as the "specific apple replant disease" (SARD), and is generally considered to be caused by one or many pathogenic soil microflora (Sewell et al., 198 1; Utkhede and Li, 1988; Westcott et al., 1985). This disease and other similar replant diseases of other fruit crops have been reviewed previously (Hoestra, 1968; Savory, 1966; Traquair, 1984; Yadava and Doud, 1980).

In addition to SARD, other nonspecific factors can act alone, but most commonly together with SARD, to reduce tree growth in replant sites (Yadava and Doud, 1980) in Washington State. These include nematodes, low soil $\mathrm{pH}$, toxic spray residues in the soil, soil compaction, poor irrigation practices, nutrient deficiencies, and a variety of other biotic factors such as diseases, rodents, and insects. We discuss here how a team of cooperative extension agents; specialists, allied industry personnel, and apple growers addressed these factors to develop an apple replant management educational program for the 68,000-ha apple industry of central Washington.

\section{The apple replant problem in Washington}

According to Benson (1969), the first replanting efforts in Washington State began in the 1920s with poor replant growth in old orchard soils reported about 10 years later (Snyder, 1936). Initially, the primary cause of the replant disorder was thought to be toxic soil residues of arsenic (As) deposited as a by-product of lead arsenate sprays used to control codling moth. Lead arsenate was used for 30 years prior to the introduction of DDT in 1948.

However, even though poor growth had been noticed from the 1930s until the 1960s, orchards in Washington State grew well "as long as they were planted with As-free soil, so they could get started" (Benson, 1969). Beginning in the 1960s, apple growers began to have greater difficulties establishing apple trees on old orchard soils. Benson (1969) attributed this to the introduction of sprinkler irrigation to replace furrow irrigation, resulting in a gradual leaching of As residues from the top layers of the soil to a more damaging situation in which a substantial portion of the root zone was contaminated. This situation also may have been compounded by the introduction of "spur"-type strains of 'Delicious' in the late 1950s. Spur strains on replant sites became spur-bound, had poor shoot growth and excessive fruiting, resulting in insufficient bearing surface (Barritt, 1992).

Prescriptions were developed (Table 1) to help growers assess the risk of planting trees in soils with As contamination; however, certain anomalies could not be ignored. Sometimes apple trees also grew poorly in old apple orchards that had minimal soil As levels. On the basis of work reported from Europe (Hoestra, 1968), soil fumigation research was initiated in Washington State in the early 1970s (Benson et al., 1974). This research demonstrated excellent tree growth even on replant soils with As residues as high as $150 \mathrm{ppm}$.

In the late 1960s and early 1970s, there was substantial grower interest in finding an easy and reliable method to ensure adequate replant growth following winter freezes that caused severe low-temperature injury to many orchards. Furnishing As-free soil to replace the replant soil in each tree hole was awkward and costly, requiring $0.5 \mathrm{~m}^{3}$ of soil to ensure satisfactory tree growth. Based on 2 years of 
Table 1. Interpretation and recommendations for managing orchard soil arsenic levels at given depths (Dow et al., 1983).

\begin{tabular}{|c|c|c|}
\hline $\begin{array}{l}\text { Soil depth } \\
\text { (feet) }\end{array}$ & $\begin{array}{l}\text { Arsenic level } \\
\text { (ppm) }\end{array}$ & Interpretation and recommendations \\
\hline $0-3$ & $<25$ & Probably not a problem. \\
\hline $0-1$ & $25-50$ & May reduce growth of sensitive trees, such \\
\hline $1-3$ & $<25$ & $\begin{array}{l}\text { as apricot and peach. Should not seriously } \\
\text { affect growth of apple, pear, and cherry. }\end{array}$ \\
\hline $0-3$ & $25-50$ & $\begin{array}{l}\text { Symptoms of As toxicity may appear on } \\
\text { apricot and peach during hot summer. } \\
\text { Newly planted apple, pear, and cherry } \\
\text { may be reduced in growth, but should still } \\
\text { grow well. }\end{array}$ \\
\hline $0-1$ & $50-100$ & Survival of apricot and peach doubtful un- \\
\hline $1-3$ & $<25$ & $\begin{array}{l}\text { less planted with As-free soil. Symptoms } \\
\text { of As toxicity should be severe on estab- } \\
\text { lished apricot and peach. May limit growth } \\
\text { of newly planted apple, pear, and cherry. }\end{array}$ \\
\hline $0-3$ & $5-100$ & $\begin{array}{l}\text { Significant reduction in growth of any } \\
\text { newly planted trees should be anticipated. } \\
\text { Avoid planting stone fruits. }\end{array}$ \\
\hline $\begin{array}{l}0-1 \\
1-3\end{array}$ & $\begin{array}{l}>100 \\
>50\end{array}$ & $\begin{array}{l}\text { Hazardous to plant any new trees under } \\
\text { these conditions. }\end{array}$ \\
\hline
\end{tabular}

research success with soil fumigation (Benson et al., 1974), growers were encouraged to try soil fumigation at the rate of $0.45 \mathrm{~kg}$ of methyl bromide (MB) per tree site. Widespread on-farm experimentation was conducted in 1974 (R.P. Covey, personal communication). However, the spring of 1974 was cool and wet-conditions that were unfavorable for dissipation of the fumigant. Upon planting, 3 weeks after fumigation, many trees died or performed poorly due to toxic MB residues (Benson et al., 1975).

For the next 10 years, very few replanted apple orchards were fumigated prior to planting because of fears about the dangers of phytotoxicity caused by fumigation. Additionally, even if trees had not been killed, some growers believed that fumigation had failed to ensure adequate tree growth. During that decade, many replanted orchards grew poorly with relatively low yields (Mokotjo et al., 1987a). This situation would have been disastrous, but Washington apple growers were receiving high prices for 'Delicious'. The apple industry in Washington also was expanding rapidly (Garret et al., 1987), moving into irrigation districts in the Columbia Basin and lower Yakima Valley. These orchards of newer, more highly colored 'Delicious' strains were planted on land taken out of sagebrush or previously planted to other crops, eliminating the need for concern about replant problems. As these orchards began to produce substantial crops in the early 1980s, the economic impact of lower yields and less fruit color in older orchard districts began to put substantial economic pressure on these growers. Because the best sites in the older districts already were planted to fruit (generally apples), and expansion in these areas was limited by the availability of irrigation water, the only choice was to renew existing orchards.

\section{Needs assessment}

The early 1980s saw an almost complete personnel change in the Washington State Univ. (WSU) Cooperative Extension county agent and subject-matter specialist positions with tree fruit responsibility. As these individuals began to develop educational programs, replant problems were identified as a priority of fruit growers in older orchard districts in the Pacific Northwest.

A 1984 key informant survey (Butler and Howell, 1980) of fruit growers in the older orchard districts of the Yakima Valley indicated that getting young trees to grow in old orchard soils was the primary concern of growers in these areas (Wohld, 1986). On-site assessment of replanted orchards in these districts confirmed the widespread nature of poor replant growth. The situation was similar throughout the region. Slykhuis (1986) noted that British Columbia apple growers also were experiencing similar problems in replanting old orchard sites. Although the benefits of soil fumigation prior to replanting had been demonstrated for almost 15 years, many growers still attributed poor growth solely to As residues from lead arsenate sprays. Old orchard soils in these areas were referred to as "leaded," with poor tree growth and productivity considered unavoidable.

Although very few orchards were being fumigated prior to replanting, the extension tree fruit team also realized that fumigation would not correct all the potential causes of poor tree growth in replanted orchards. Some orchard soils had $\mathrm{pH}$ levels lower than 5.0 in a specific pattern underneath the tree canopy, caused by yearly nitrogen fertilizer applications (Fig. 1), which led to manganese toxicity in newly planted 'Delicious' orchards (Tukey et al., 1984). The widespread nature of the low $\mathrm{pH}$ problem in central Washington had not been recognized widely. Older trees, with their extensive root systems, generally did not show manganese toxicity symptoms, and soil testing was not used routinely. Some soils were severely compacted from decades of equipment travel in the drive rows (Stevens, 1986). As nursery trees were planted into previous drive rows when the orchard spacing changed, the trees grew poorly. Sprinkler system mainlines and laterals conserved from the previous orchard often had extremely poor coefficients of uniformity and were unable to irrigate new plantings adequately (Ley, 1986).

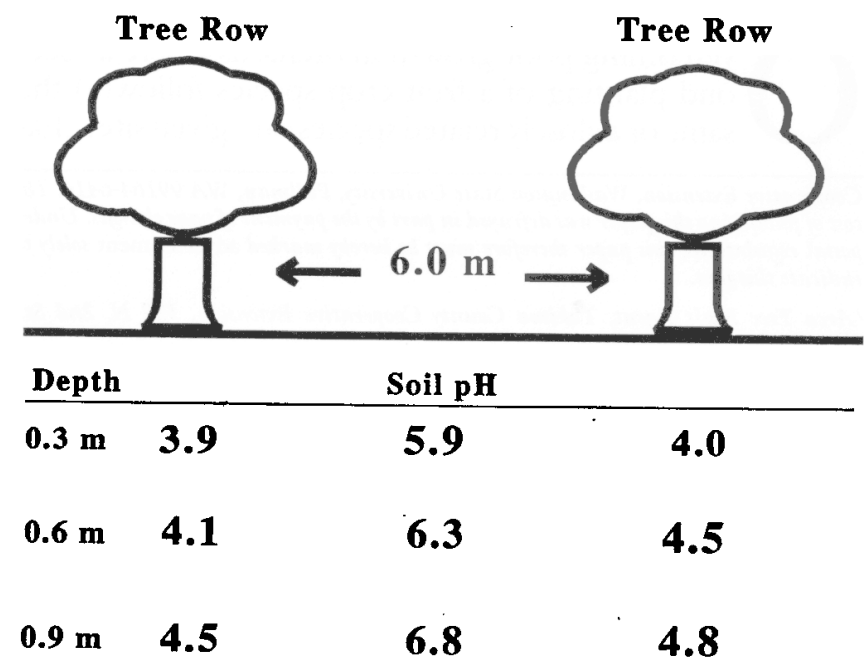

Fig. 1. Typical soil $\mathrm{pH}$ distribution in a mature Washington orchard after banded $N$ fertilizer applications in the tree row (Smith, 1986a). 
Because yield expectations in replanted orchards were so poor, most orchards were renewed by interplanting (Mokotjo et al., 1987a). Interplanting is a process of planting a young tree between each existing tree in the row and gradually pruning back and removing the older tree as the interplant comes into production. Adequate soil preparation is impossible in interplanted orchards. Because growth of replanted orchards was less than desirable, most growers used seedling rootstock to promote growth at the expense of precocity (Larson and Fritts, 1982; Seeley et al., 1979).

While nematodes also have been reported to be a factor in the replant problem in other apple-growing regions (Yadava and Doud, 1980), surveys and field experience indicate that damaging nematode populations were not found commonly in eastern Washington apple orchards (G.S. Santo, personal communication). Covey et al. (1979) found that nematodes were not the primary cause of replant problems in central Washington. The presence of flat apple disease (Zawadyka and Millikan, 1989), caused by a virus transmitted by the dagger nematode (Xiphenema spp.) and only identified in orchards west of the city of Yakima, would not affect the grower's decision to fumigate. However, the presence of this virus would justify broadcast fumigation rather than strip applications when fumigating replant sites (Willett et al., 1993).

\section{Educational program planning and delivery}

The 5169 apple growers in Washington (U.S. Dept. of Commerce, 1989), all of whom who had potential replant challenges, were the primary audience for replant education programs. Another key audience was the orchard management consultants and packinghouse field representatives who have daily contact with these growers. These individuals play a prominent role in developing and extending technical information to their grower/clients and area focus of Washington State Univ. Cooperative Extension programs. Because of their educational background (most have BS degrees in horticulture or plant protection) and the competitive need to stay abreast of new technology, specific, highly technical educational programs were developed for this audience.

These educational programs began with a focus on helping growers adopt appropriate cultural practices to ensure growth of young apple trees in old orchard soils. As the educational program evolved to answer questions raised by the audience-the focus of the program changed to include information on replant economics and total orchard system evaluation. Because the potential audience was not homogeneous, the educational program was delivered using a variety of methods to reach as many growers as possible, regardless of their learning style.

Overcoming replant disease. The initial thrust of the educational program was to help growers understand the impact of soil biological factors (nematodes, SARD), As residues, soil $\mathrm{pH}$, inadequate irrigation, soil compaction, and soil fertility on tree growth. Changing existing replant cultural practices was essential for successful orchard replanting. Growers and allied industry personnel were cautioned that, although SARD was the most common limiting factor in the replant problem, other possible limiting factors also existed.

Program delivery in this area was divided into four general categories: "Classroom" sessions, field tours, industry and trade journal articles, and applied on-farm demon- strations. The classroom sessions ranged from focused seminars on orchard renewal for growers and consultants to presentations at statewide or local grower meetings (Ley, 1986; Smith, 1986a,1986b; Stevens, 1986; Willett et al., 1988 ). Field tours were conducted to assess renewal needs in existing orchards, to view the continuing effects of proper orchard renewal in research plots developed during the early 1970s, and, eventually, to observe the results of on-farm trials conducted by cooperative extension and individual growers (Willett et al., 1989). The on-from demonstrations conducted by cooperative extension were designed to show the effects of fumigation and other soil amendments in settings that were familiar to local growers. Articles about proper orchard renewal appeared in local newspapers, general farm journals (Wohld, 1986), and fruit industry publications (Smith 1987; Smith, 1989a,1989b; Willett and Peterson, 1990).

Replant economics. As growers and consultants with replant concerns participated in the seminars and field tours, questions were raised about the added costs necessary to ensure adequate growth, and whether these costs could be justified. In response to those concerns, an economic analysis of two existing types of orchard renewal-interplanting and whole-block removal-was conducted to establish base costs and yield expectations (Mokotjo et al., 1987a, 1987b). These studies were conducted by gathering a representative group of growers and asking them over a period of several meetings to estimate their expected production practices, costs, and yields for replanted orchards. Although the cost of fumigation was included, none of the growers had direct experience with fumigation, so they based yield projections on their previous experiences with yields from nonfumigated replant sites. Results of these studies showed that, given the growers' yield expectations, accumulated interest costs had eliminated any chance for a reasonable profit. Managing SARD and all potential replant disorders could cost an additional $\$ 3000 /$ ha. A profitable orchard could be expected if yields were similar to those in previous replantfumigation trials (Koch et al., 1980). Once these studies were completed, this information was integrated into the replant education program.

Orchard systems. While 'Delicious' is the dominant variety in Washington State, lower returns for that variety began in the mid-1980s. These lower returns raised fears about the profitability of any new 'Delicious' plantings, particularly replanted 'Delicious' orchards with higher establishment costs. In 1987, interest increased substantially in alternative apple varieties, with a greater potential for return to the grower (Fleming, 1988; Norton, 1988). Because of the more vigorous growth and the fruiting habit of many of these varieties (i.e. 'Fuji', 'Jonagold', and 'Gala'), growers also began expressing interest in dwarfing rootstock such as M.26 or M.9. Along with these more-dwarfing rootstock came an interest in higher-density orchards and training systems, such as the slender spindle and the vertical axis (Barritt and Dilley, 1989).

The management program for the establishment and maintenance of fruit tree plantings based on the successful integration of horticultural components (rootstock, tree density and arrangement, tree quality, pruning and training techniques, and support system) is called an orchard system (Barritt, 1992). The increased emphasis on orchard systems research and education (Peterson, 1989 ) in Washington State in the late 1980s became an integral part of the answer 
to growers' questions about orchard renewal.

The orchard system educational program was supported and integrated with an orchard systems research project begun at the WSU Tree Fruit Research and Extension Center in 1985. Tours were conducted of the orchard systems trial planted as part of the research project and yearly updates were presented at grower educational forums. An extensive economic analysis of the original 1985 'Granny Smith' planting was prepared (Barritt and Hinman, 1992; Barritt et al., 1992).

In 1990, a five-site orchard systems trial of 'Golden Delicious' on M.9, M.26, and M.7 was planted at three different densities and trained to slender-spindle, verticalaxis, or a central-leader training system, respectively. These trials serve as "hands-on" training locations for local growers interested in learning to manage high-density systems. Additional educational programming was earned out in the orchards of innovative growers who had experimented with high-density plantings.

To support the research and educational efforts surrounding high-density plantings, a series of economic studies was conducted. These studies centered around replanting old orchard sites using recommended orchard management systems. These studies included establishing a supported 'Jonagold' and 'Gala' apple orchard (Peterson and Hinman, 1988), replanting a high-density 'Fuji' apple orchard on M.9 rootstock using a Hybrid TreE Cone (HYTEC) system (Hinman et al., 1991), and replanting a 'Fuji' apple orchard using a double row V-trellis system (Marshall et al., 1993).

\section{Educational outcomes}

Better tree growth and production. Because growers and consultants quickly learned how to analyze the need for correction of soil physical and chemical problems, the primary challenge was to demonstrate that soil fumigation was a costeffective solution to SARD. The initial fumigation trials were conducted in small areas of cooperators' orchards. The data represented in Fig. 2 are from a demonstration orchard planted in 1987 at the Lloyd Garretson Company orchard near Yakima. The planting site was limed, sub-soiled, and double- cropped with Sudan grass and buckwheat in the year prior to planting. Each treatment was applied to single-tree plots with 10 replicates in a randomized complete-block design. The blocks are separated by a single guard tree in each row.

These data represent the improvement in early growth of 'Red Chief Delicious' on MM. 106 rootstock due to soil fumigation in an orchard site where other potential limiting factors had been corrected. The trees treated

Fig. 2. Trunk cross-sectional area $\left(\mathrm{cm}^{2}\right.$ after 4 years in the Lloyd Garretson orchard in the Yakima Valley for four preplant treatments and a control (no preplant treatment). $C k=$ check, $M B=$ methyl bromide applied at 0.45 $\mathrm{kg} /$ tree site, $M A P=11-55-0$ applied at 227 g/tree site, and MS = mtham sodium applied at 0.47 liters/tree site. $M B+M A P=a$ combination of methyl bromide and 11-55-0 applied at the rates given above. Bars represent SE of the mean. with methyl bromide (MB) or sodium methyl dithiocarbamate, commonly known as metham sodium (MS), grew much better than the untreated trees or trees treated with monoammonium phosphate (MAP) alone. Work in British Columbia suggests that MAP can increase first-year growth and improve precocity of replanted orchards (Neilson and Yorston, $1991)$. In the 4th year, this trial yielded the equivalent of 6.0, 19.5, 21.2, 10.1, and 15.0 t.ha ${ }^{-1}$ from the control, MB, MB and MAP, MAP alone, and MS treatments, respectively.

MB improved yield relative to MAP plus $0.05 \mathrm{~m}^{3}$ of arsenic-free soil, or new soil alone in a replanted orchard site near Wenatchee (Fig. 3). The orchard was planted in Spring 1986 to 'Royal Gala' on seedling rootstock (Smith, 1994). Because this was the first replant education program orchard trial, it was instructive to note the yield improvements produced by soil fumigation. It was as beneficial to note that the vigor of seedling rootstock alone did not result in sufficient productivity to obscure the benefits of fumigation.

These numerous (five in Yakima and 24 in the Wenatchee district), small replant plots established in central Washington by cooperative extension personnel were extremely instructive. For growers and consultants, they were highly visual demonstrations of the benefits of correct soil preparation, including fumigation. For cooperative extension, they were a validation of the $200 \%$ to $300 \%$ yield increases that were predicted by early fumigation research (Koch et al., 1980) and indicative of what growers could expect on their own farms.

Performance of metham sodium. While MB is still the standard by which other SARD controls are measured, concern with it as the only available fumigant led to the testing of MS as an alternative to MB (Fig. 2). Preliminary application rate studies in a 'Gala'/M.7 orchard near Wenatchee (Fig. 4) indicate that 935 liters of a 33\% formulation of MS product per treated ha [357kg (a.i.)/ha per ha) is the optimum rate (Smith, 1994).

A recent trial using this rate of MS compared to the standard rate of MB (Fig. 5) shows that MS resulted in higher 'Delicious' yields than MB in the 4th season ( 1991 ) after planting, but no difference in the 5th year (1992) (Smith, 1994). When used on other crops in the Pacific

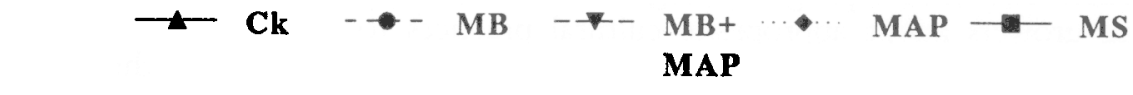

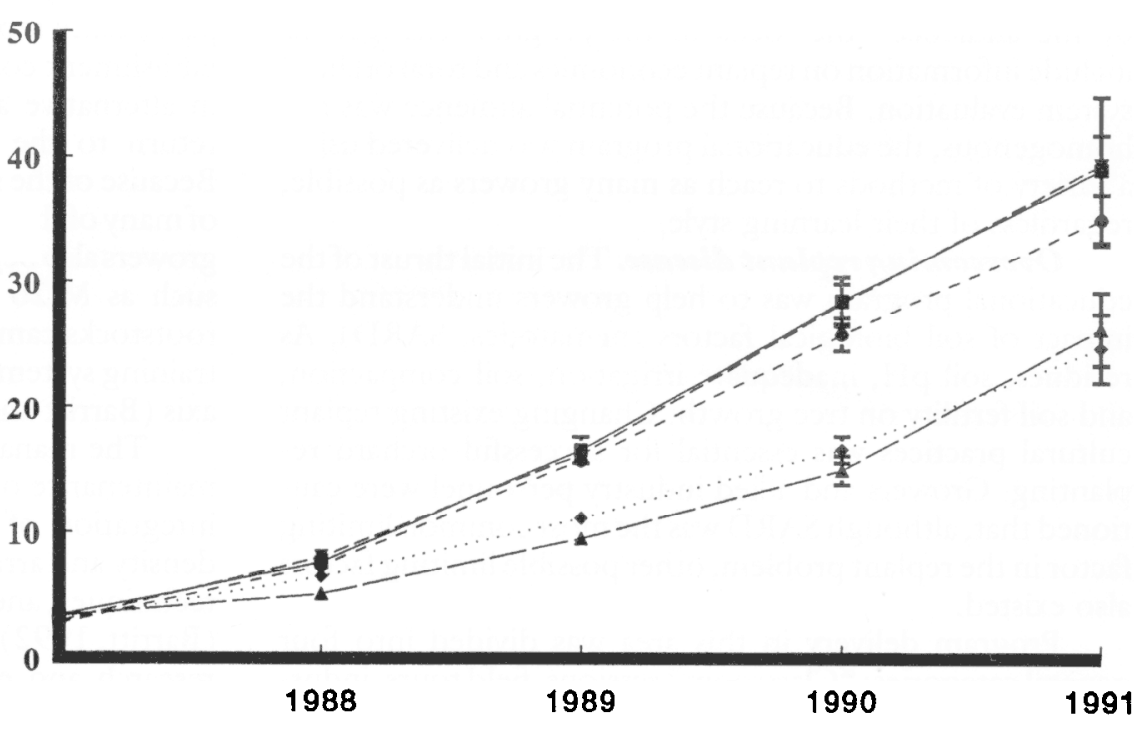




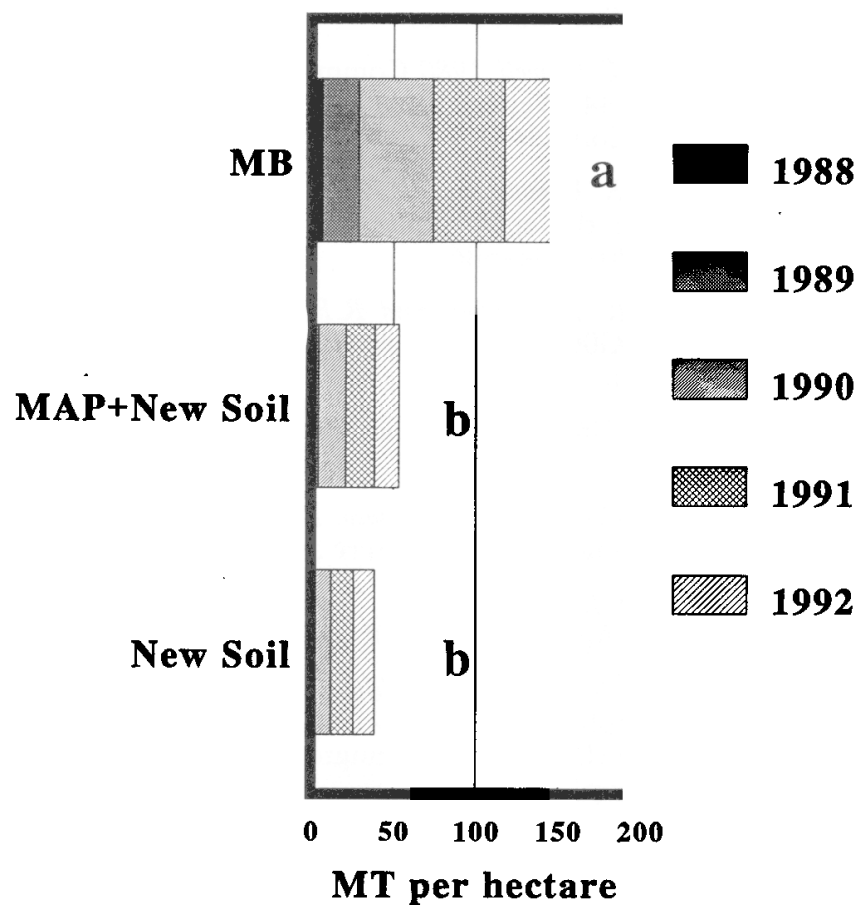

Fig. 3. Cumulative yields $\left(t \cdot h a^{-1}\right)$ for three preplant treatments in the Greenacres Orchard near Wenatcbee. MB. methyl bromide applied at $0.45 \mathrm{~kg} /$ tree site, MAP + new soil $=11-55-0$ applied at $224 \mathrm{~g} /$ tree site plus $0.05 \mathrm{~m}^{3}$ of new soil/tree site, and new soil $=0.05 \mathrm{~m}^{3}$ of new soil/tree site. Letters indicate mean separation of cumulative yields by Duncan's multiple range test with $\mathrm{P} \leq 0.05$.

Northwest, MS has been most effective when injected into sprinkler systems and applied in the irrigation water. In those crops (primarily potatoes), physical preplant incorporation of MS into the soil did not produce the desired response. Many successful experimental trials of MS have been conducted in orchards using standard orchard weed sprayers to apply the MS. It is banded over the new tree row while applying $25 \mathrm{~mm}$ of water through the sprinkler system to ensure the movement of MS into the effective tree root zone. Label modifications allowing this method ofapplica-

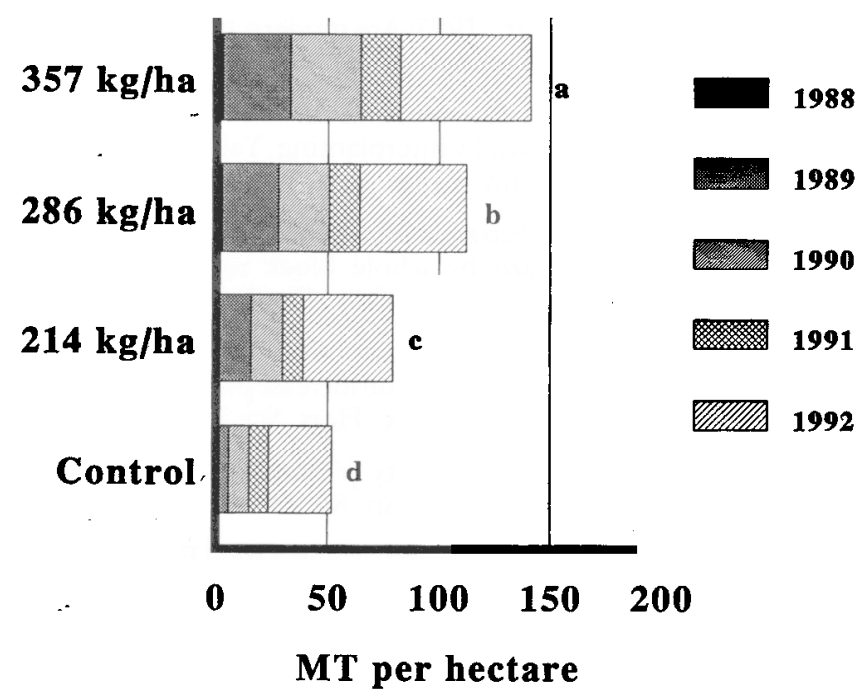

Fig. 4. Cumulative yield for three Fall 1985 application rates of metham sodium (MS) $(214,286$, and $357 \mathrm{~kg}$ a.i./ha) and a control (no MS applied). The trees were planted in 1987. Letters indicate mean separation of cumulative yields by Duncan's multiple range test with $\mathbf{P}$ $\leq 0.05$.

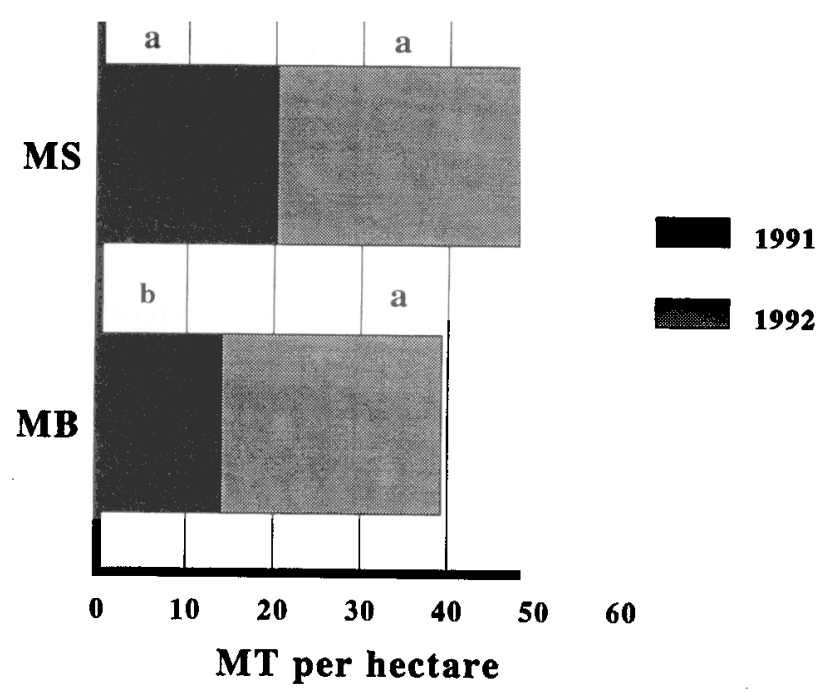

Fig. 5. Cumulative yield ( $\left.t \cdot h a^{-1}\right)$ for a comparison of two preplant soil fumigants. $M B=$ methyl bromide-applied at $0.45 \mathrm{~kg} /$ tree site and $M S=$ metham sodium broadcast at the rate of 935 liters $/ \mathrm{ha}(357 \mathrm{~kg} \mathrm{a.i./ha})$. Letters indicate mean separation of annual yields by Duncan's multiple range test with $\mathrm{P} \leq 0.05$.

tion in Washington under the FIFRA 24-C provisions were approved for three registrants in late 1992.

Widespread use of fumigation. Of the two fumigants used most commonly, actual use data are available only for $\mathrm{MB}$ because there is a single-source supplier for the material. The use of MB in orchard renewal has gone from 80 ha treated in Fall 1980 and Spring 1981, to 500 ha treated in Fall 1990 and Spring 1991. In 1992 and 1993, an average of 300 ha was treated each year (D. Richmond, personal communication). A 1991 survey of growers who replanted 440 ha in the Wenatchee area indicated that $84 \%$ were fumigated with either MB or MS (T. Smith, personal communication).

MS is available from a number of chemical formulators and is sold through many distributors. Use estimates from suppliers indicate that MS was used on 400 ha in the Yakima Valley during 1992-93. No metam sodium was used for orchard renewal prior to 1987.

New varieties and orchard systems. Orchardists are changing over to high-density orchards of newer varieties (Marshall and Andrews, 1994). In 1986, only 20\% of new plantings had $>1482$ trees/ha. In 1992, 55\% of plantings had 1482 or more trees/ha on rootstock such as M.26, M.9, and Mark (Buckner, 1993). New varieties are now more important than ever. In 1986, 'Fuji' was $0.3 \%$ of new plantings. In 1992, 'Fuji' was 34\% of new plantings. 'Delicious', which was $35 \%$ of new plantings in 1986, was $10 \%$ of new plantings in 1992 (Hasslen and McCall, 1994).

\section{Summary}

This educational program helped apple growers learn to overcome physical, chemical, and biological barriers in replanting old orchard sites. Fumigation is an important tool in the strategic management of the apple replant problem in Washington State. However, concern has been raised (Merwin and Pritts, 1993) about the acceptability of soil fumigants for this purpose. MB has been implicated as a Class I ozone depleter and is scheduled for a phase-out by the beginning of the next century (U.S. Federal Register, 1993). MS, an entirely different type of fumigant, has not been targeted for regulatory removal. Still, it is dangerous to 
rely on a single tool for SARD management. Research should continue to pursue alternatives to soil fumigation, such as improved methods of soil polarization, biological control of SARD pathogens, and other cultural controls.

Thus far, there are four main reasons for the success of this educational program. First, the initial efforts in replant education were based on a real need of apple growers regardless of their location or operation size. Second, it was a statewide effort involving a large number of extension and research faculty, growers, and allied industry personnel throughout central Washington. The size of the project was not only defined by the number of contributors, but also by its scope. It was critical that agricultural lenders, community leaders, and other key decisionmakers were aware of what was necessary to continue to have profitable, sustainable orchards in old orchard districts. Their perceptions of orchard economic viability in these areas have an impact on socio-economic decisions that can, in turn, have a major impact on orchardists. Third, a significant research base existed upon which the education program was built. A research base of this type is essential to development of quality extension programs. Finally, the entire tree fruit team responded to the changing needs of the clientele as new questions arose during the educational programs. This flexibility on the part of the team prevented the effort from bogging down when tough, new questions were asked.

There has been a remarkable revolution in the production practices, orchard designs, and varieties in Washington State. In large part these changes were driven by economics. It is a tribute to the Washington State fruit industry that it was able to change to meet these economic challenges. We believe that the efforts outlined here to overcome poor tree performance on replant soils played a significant role in helping growers meet these challenges, but we did not do it in a vacuum. This effort is a re-validation of the classic extension methods pioneered by Seaman Knapp and a tribute to the effectiveness of forging an interdisciplinary partnership between producers, extension field staff, and research (Juchartz, 1992).

\section{Literature Cited}

Barritt, B.H. and M.A. Dilley. 1989. Results of apple high-density orchard systems trials in north central Washington. Proc. Wash. State Hort. Assn. 84:187-191.

Barritt, B.H. 1992. Intensive orchard management. Good Fruit Grower, Yakima, Wash.

Barritt B.H. and H.R. Hinman. 1992. Economic and horticultural analysis of apple orchard systems with 'Granny Smith'. Good Fruit Grower 43(16):32-36.

Barritt, B.H., H.R. Hinman, K. Williams, M.A. Dilley, L. Heavey. 1992. Economic analysis of a 'GrannySmith' apple orchard systems trial. XB 1024. Washington State Univ. College of Agriculture and Home Economics Research Center, Pullman.

Benson, N.R., R.P. Covey Jr. and W.R. Haglund. 1975. The hazards of soil fumigation. Proc. Wash. State Hort. Assn. 70: 108-1 09.

Benson, N.R., R.P. Covey, Jr. and W.A. Haglund. 1974. Soil fumigation helps replants in old apple orchards. Proc. Wash. State Host. Assn. 69:90-96.

Benson, N.R. 1969. Can profitable orchards be grown on old orchard soil? Proc. Wash. State Hort. Assn. 64:109-114.

Buckner, L.R. 1993. Apple and pear variety planting trends. Proc.
Wash. State Hort. Assn. 88:36-46.

Butler, L.M. and R.E. Howell. 1980. Community needs assessment techniques. WREP 44. Western Rural Development Center, Oregon State Univ., Corvallis.

Covey, R.P., Jr., N.R. Benson, and W.A. Haglund. 1979. Effect of soil fumigation on the apple replant disease in Washington. Phytopathology 69(6):684-686.

Dow, A.I. and A.R. Halvorson, and R.B. Tukey. 1983. Special orchard soil tests. FG0028d. Washington State Univ. Cooperative Extension, Pullman.

Fleming, D. 1988. Alternative varieties. Proc. Wash. State Hort. Assn. 83:115-118.

Garret, L., J. McCall and H. Nishimoto. 1987. Washington fruit survey 1986. Washington Agr. Stat. Serv., Olympia.

Hasslen, D.A. and J. McCall. 1994. Washington Fruit Survey 1993. Washington Agr. Stat. Serv., Olympia.

Hinman, H.R., A.B. Peterson, K, Williams, and K. Maib. 1991. Estimated cost of replanting to a high-density 'Fuji' apple orchard on full dwarf rootstock in central Washington. EB 1635. Washington State Univ. Coop. Ext., Pullman.

Hoestra, H. 1968. Replant diseases of apple in the Netherlands. Meded. Landbouwhogesch. Wageningen. 68-13.

Juchartz, D.D. 1992. Participatory research and education. HortTechnology 2:428 (lett.).

Koch, B.L., R.P. Covey, and W.R. Haglund. 1980. Effect of soil fumigation on the early growth and production of 'Delicious' apple trees. J. Amer. Soc. Hort. Sci. 105:837-890.

Larson, F. E. and R. E. Fritts Jr. 1982. Sixteen year summary of apple rootstock influence on yield, yield efficiency and trunk growth. J. Amer. Soc. Hort. Sci. 107:23-27.

Ley, T.W. 1986. Irrigation systems and water management considerations. Proc. Wash. State Hort. Assn. 81:151-162.

Marshall, D., K. Maib, A.B. Peterson, and H. Hinman. 1993. Estimated cost of replanting an apple orchard to a double row $\mathrm{v}$ trellis high-density system in central Washington. EB 1735. Washington State Univ. Coop. Ext., Pullman.

Marshall, D.W. and P.K. Andrews. 1994. Trends in Washington State's apple industry. HortTechnology 4(1):6-15.

Merwin, I.A. and M.P. Pritts. 1993. Are modern fruit production systems sustainable? HostTechnology 3(2):128-136.

Mokotjo, J., H. Hinman, B. Peterson, and M. Willett. 1987a. Cost of replanting an apple orchard by interplanting, Yakima Valley. EB 1567. Washington State Univ. Coop. Ext., Pullman.

Mokotjo J., H. Hinman, B. Peterson, and M. Willett. 1987b. Cost of replanting an apple orchard by whole block removal, Yakima Valley. EB 1428. Washington State Univ. Coop. Ext., Pullman.

Neilson, G.H. and J. Yorston. 1991. Soil disinfection and monoammonium phosphate fertilization increase precocity of apples on replant problem soils. J. Amer. Soc. Host. Sci. 116:651-654.

Norton, R.A. 1988. The apple variety picture-new choices for growers. Proc. Wash. State Hort. Assn. 83:98-108.

Peterson, A.B. (ed.) 1989. Intensive orcharding. Good Fruit Grower, Yakima, Wash.

Peterson, A.B. and H. Hinman. 1988. Cost of establishing a 'Jonagold' or 'Gala' apple orchard in central Washington. EB 1312. Washington State Univ. Coop. Ext., Pullman.

Savory, B.M. 1966. Specific replant diseases. Commonwealth Bur. of Horticulture and Plantation Crops. Commonwealth Agr. Bur. East Mailing, Maidstone, Kent., U.K. Res. Rev. 1. 
Seeley, E.J., E.A. Stahly, and R. Kammereck. 1979. The influence of rootstock and strain on growth and production of 'Delicious' and 'Golden Delicious' apple trees. J. Amer. Soc. Hort. Sci. 104:80-83.

Sewell, G.W.F., V.J. Freeman, B. Sivakadadeham, and J. Pullinger. 1981. Apple replant disease and soil fumigation (08005). Rpt. E. Mailing Res. Sta. (1980):78-79.

Slykhuis, J.T. 1986. Tests for control of apple replant problems in British Columbia. Proc. Wash. State Hort. Assn. 81:142-146.

Smith, T.J. 1986a. Some soil quality factors in relation to replant. Proc. Wash. State Host. Assn. 81:146-150.

Smith, T.J. 1986b. Some aspects of orchard site preparation. Proc. 19th Annu. British Columbia Fruit Growers Assn. p. 9-13.

Smith, T.J. 1987. Improve growth of young trees, maintain your orchard productivity. Good Fruit Grower 36(3):20-21.

Smith, T.J. 1989a. Treatments are important for successful replants. Western Fruit Grower 109(8):17.

Smith, T.J. 1989b. Avoid replant problems. Western Fruit Grower 109(4):36B-36C

Smith, T.J. (1994). Successful management of orchard replant disease in Washington. Acta Hort. (In press.)

Snyder, I.C. 1936. Crops planted in pulled orchards. Proc. Wash. State Hort. Assn. 31:48-54.

Stevens, R. G. 1986. An overview of replant problems. Proc. Wash. State Hort. Assn. 81:132-142.

Traquair, J.A. 1984. Etiology and control of orchard replant problems: A review. Can. J. Plant Pathol. 6:54-62.

Tukey, R.B., A.I. Dow , and A.R. Halvorson. 1984. Fertilizer guide for fruit trees. FG0028a. Washington State Univ. Coop. Ext., Pullman.

U.S. Dept. of Commerce, Bureau of the Census. 1989. 1987 census of agriculture. Geographic Area Ser. Part 47. Washington state and county data.

U.S. Federal Register. 1993. EPA. 40 CFR, Part 82. Protection of stratospheric ozone; proposed rule. 18 Mar.

Utkhede, R.S. and T.S.C. Li. 1988. The role of fungi, bacteria and their instructions in apple replant disease complex in soils of British Columbia. Acta Hort. 233:75-80

Westcott, S.W. III, S.V. Beer, and W.C. Stiles. 1987. Infection of apple roots by actinomycetes associated with soils conducive to apple replant disease. Plant Dis.70: 1125-1128.

Willett, M.J., D. Allan, G. Vradenburg, and D. Evans. 1988. Handing poor tree growth. Proc. Wash. State Host. Assn. 83:78-83.

Willett, M. J., A. B. Peterson, G. Menzies and L. Mrachek. 1989. Specific apple replant disease. 63rd Annu. Western Orchard Pest and Disease Management Conf., Portland, Ore. 63:5-6.

Willett, M.J. and B. Peterson. 1990. Soil preparation for successful replant establishment should begin now. Good Fruit Grower $41(12): 36$

Willett, M.J., R.G. Stevens, and T.J. Smith. 1993. Growing young trees in old orchard sites. PNW 0414. Washington State Univ. Coop. Ext., Pullman.

Wohld,M. 1986. Restoring old orchard soils. Washington FarmerStockman. Inland ed. 7 Aug. 1986. p. 11-12.

Yadava, U.L. and S.L. Doud. 1980. The short life and replant problems of deciduous fruit trees. Host. Rev. II:1-116.

Zawadyka, B. and D.F. Millikan. 1989. Other infectious diseases of apple, p. 157-161. In: P.R. Fridlund (ed.). Virus and virus like diseases of pome fruits and simulating noninfectious disorders SP0003. Washington State Univ. Coop. Ext., Pullman. 